\title{
INFLUENCE OF FINANCIAL REGULATIONS ON EARLY-STAGE ENTREPRENEURIAL ACTIVITY
}

\section{Goran Avlijaš}

Singidunum University, Belgrade, Serbia

\begin{abstract}
:
Government efforts to provide better business environment in terms of high-quality regulations and business laws should facilitate the development of entrepreneurial activity in different ways. There is an emerging body of literature that supports this relationship. The aim of the paper is to examine how different kinds of financial regulations, such as government procedures for getting credit, paying taxes and resolving insolvency, are related to the formation of young businesses. The sample includes World Bank's Doing Business and Global Entrepreneurship Monitor data for 50 economies within the period of two years. The analysis has confirmed that financial regulations can have a significant impact on the early-stage entrepreneurial activity rate, but this relationship should not be a priori defined as generally positive.
\end{abstract}

Keywords:

entrepreneurship, financial policy, doing business, regulations.

\section{INTRODUCTION}

It is estimated that more than $90 \%$ of jobs in developing economies is created through private sector, small and medium-sized enterprises and entrepreneurship (Stampini et al. 2011). Governments tailor their policies to facilitate and support sound business environment, characterized by greater business opportunities, jobs creation, increasing investments and productivity. Although most of these policies still focus on macroeconomic factors, there is an emerging body of literature that calls for more attention to the matter of quality of regulations, laws and institutional support, which impacts business life on a daily basis (Alesina et al. 2005; Klaper et al. 2009; Fisman \& Sarria-Allende, 2010; Perotti \& Volpin, 2005).

Well-designed business policies and regulations should enable development of private sector and business network. On the other hand, poorly designed regulations that should support and protect economic activity and business operations, can become a major obstacle in this process. This scenario can easily become reality, having in mind the dynamics and challenging nature of the existing business environment where regulations and policies must continually improve and adapt to new business conditions. An increasing use of information and communication technology in business processes is just one of the reasons for adaption of business regulations.

The primary goal of the paper is to investigate the link between the observed level of financial regulation and new firm formation. The study included 50 countries observed during a period of two years and it suggests that the association between the financial regulation of starting a business and entrepreneurship is by no means as clear as implied in the existing literature. However, it does find that financial regulations can have a significant impact on early-stage entrepreneurial activity. The overall conclusion is that there is a need for a serious review policy in this area, with better and larger datasets as a key requirement. 


\section{THEORETICAL BACKGROUND}

In order to examine the indicators of financial regulation, this research focuses on three indicators measured by the World Bank's Doing Business project: Getting credit, Paying taxes and Resolving insolvency. The selection of indicators of financial regulations was based on the insights from the extensive research literature (such as Djankov et al. 2007; Djankov et al. 2008; Djankov et al. 2010), and some of those sources and their findings are presented in the following part.

Doing business project assesses credit registries, legal rights of borrowers in secured transactions and bankruptcy laws, as systems that can have impact on access to finance and its allocation. Djankov et al. 2007 state that these systems function best together. Creditors assess the creditworthiness of clients based on the information provided by credit bureaus, and legal rights can make easier the use of collateral and enforce claims in the event of default. Insolvency regimes and creditor rights can significantly improve commerce and economic growth, as they represent the basis of the sound investment ambience (World Bank, 2011).

Infrastructure of the financial market, which includes courts, credit-collateral registries, and creditor and insolvency laws, directly provides easier access to credit, which is one of the main obstacles identified by businesses worldwide. Strong collateral laws supported by efficient credit information system can help to overcome this problem. A recent study performed on a sample of 12 economies has confirmed that improving the collateral law may have positive effects on the volume of bank lending (Haselmann et al. 2010).

Increase of information sharing through credit registries should lead to lower bank risks and higher bank profitability. In addition, the existence of public/private credit registries and stronger creditor rights is associated with higher ratio of private credit to GDP (Djankov et al. 2007; Houston et al. 2010). Several studies conducted in India, Brazil, Columbia and Belgium pointed out to debt recovery and exit processes as the key towards determining credit conditions (Visaria, 2009; Funchal, 2008; Gine \& Love, 2008; Dewaelheyns \& Van Hulle, 2008).

Tax policy is another significant aspect of financial regulations. When it comes to paying taxes, it seems that there is a close connection between administrative burden, tax rates and investments. Many economies have concurrently reduced administrative burden and tax rates to stimulate the economic activity. The data on total tax rates and investments examined in the last decade indicate that the reduction of tax rate by one percent leads to an increase of investment by $1 \%$ of GDP (Eifert, 2009).

As a result of the financial crisis, academics, practitioners and policy makers highlight the importance of efficient insolvency administration in recovering local economies, while also discussing different approaches to bankruptcy reform implementation. The literature elaborated on different effects that efficient insolvency laws and restructuring framework can have on business, such as: assistance in restructuring and survival of private entities (Rizzo, 2011), strengthened secured creditors' rights, and reduction in the cost of debt (De Araujo, 2011).

\section{METHODOLOGY}

The data used come from two primary sources: Doing Business (DB) project and Global Entrepreneurship Monitor (GEM) study. The World's Bank DB project delivers annual reports and quantitative indicators on business regulations for 189 economies. The goal of these reports is to examine the efficiency of applied reforms in 11 areas (starting a business, dealing with permits, getting electricity, registering property, getting credit, protecting investors, paying taxes, trading across borders, enforcing contracts, resolving insolvency and labor market regulation) and reveal difficulties for a local entrepreneur to open and run a business in compliance with these regulations (DB, 2016).

GEM was established in 1999 with the aim to measure differences in entrepreneurship attitudes and activities in various countries, to define determining factors for the nature and level of entrepreneurship activities and to establish implications of efforts to strengthen entrepreneurship. GEM data is used to produce a model connecting a series of Entrepreneurial Framework Conditions to the early-stage entrepreneurial activity, entrepreneurial aspirations, technical progress, GDP growth and other macroeconomics variables (GEM, 2016).

We have selected three financial DB indicators for the independent variables (getting credit, paying taxes, and resolving insolvency), and examined how they interact with the dependent variable Total early-stage Entrepreneurial Activity (TEA) provided by the GEM. Independent variables use values of distance-to-frontier (DTF) score, which shows how far certain economy is from the best performing economy across time. DTF score is indicated on a scale from 0 to 100 , where 0 represents the worst performance and 100 the frontier.

Research included the data for 50 countries from all continents, which had complete GEM and DB data for the last two years (2014 and 2015). Complete dataset with names of the countries is provided in Appendix 1. The data from these two sources were compiled in a single spreadsheet and analyzed using a panel regression. Statistical analysis was conducted in Stata software, and the output of descriptive statistics for all of the examined variables is shown in Table 1. Based on the descriptive statistics (overall std. dev.), it can be seen that the data significantly varies across countries for all variables.

Total early-stage Entrepreneurial Activity (TEA) variable represents the percentage of working age population actively involved in business start-ups, either as nascent entrepre- 
Table 1. Descriptive statistics of variables

\begin{tabular}{|c|c|c|c|c|c|}
\hline Variable & Mean & Std. Dev. & Min & Max & Observations \\
\hline \multicolumn{6}{|l|}{ TEA } \\
\hline overall & 13.2965 & 7.643455 & 2.93 & 37.37422 & $\mathrm{~N}=100$ \\
\hline between & & 7.470188 & 4.42102 & 33.08316 & $\mathrm{n}=50$ \\
\hline within & & 1.78392 & 7.294393 & 19.29861 & $\mathrm{~T}=2$ \\
\hline \multicolumn{6}{|c|}{ Getting Credit } \\
\hline overall & 63.8619 & 17.33791 & 15 & 100 & $\mathrm{~N}=100$ \\
\hline between & & 16.07779 & 20 & 91.875 & $\mathrm{n}=50$ \\
\hline within & & 6.687217 & 47.6119 & 80.1119 & $\mathrm{~T}=2$ \\
\hline \multicolumn{6}{|l|}{ Paying Taxes } \\
\hline overall & 73.4245 & 14.4915 & 36.34 & 95.07 & $\mathrm{~N}=100$ \\
\hline between & & 14.49696 & 36.34 & 95.07 & $\mathrm{n}=50$ \\
\hline within & & 1.401638 & 65.4195 & 81.4295 & $\mathrm{~T}=2$ \\
\hline \multicolumn{6}{|c|}{ Resolving Insolvency } \\
\hline overall & 58.6001 & 23.08075 & 16.58 & 98.3 & $\mathrm{~N}=100$ \\
\hline between & & 22.08156 & 23.8 & 95.48 & $\mathrm{n}=50$ \\
\hline within & & 7.074646 & 41.6851 & 75.5151 & $\mathrm{~T}=2$ \\
\hline
\end{tabular}

neurs or owner - manager of new firms (GEM 2016). Getting credit variable represents legal rights of borrowers and lenders with respect to secured transactions and the reporting of credit information. It measures the existence of certain features that facilitate lending within the existing collateral and bankruptcy laws, as well as the coverage, scope and accessibility of credit information available through credit bureaus or credit registries (DB 2016).

Paying taxes variable represents the taxes and mandatory contributions that a medium-sized company must pay in a given year as well as the administrative burden of paying taxes and contributions. These include the profit income tax, social contributions, labor and property taxes, dividend tax, capital gains tax, financial transactions tax, waste collection taxes, vehicle and road taxes, etc. Resolving insolvency variable treats the time, cost and outcome of insolvency proceedings involving domestic entities, as well as the strength of the legal framework applicable to liquidation and reorganization proceedings (DB 2016).

\section{RESULTS AND CONCLUSIONS}

Random-effects GLS regression was performed in order to examine the impact of independent variables (financial indicators) on dependent variable (early-stage entrepreneurship rate). The results are shown in Table 2 . The main analysis was preceded by the correlation analysis and Husman test which confirmed better fit for random-effects analysis over a fixed-effects analysis (Appendix 2). The overall model is statistically significant (Prob $>$ chi $2=0.0008$ ), as are the coefficients for variables Paying Taxes $(\mathrm{P}>\mathrm{Z}=0.02)$ and Resolving Insolvency $(\mathrm{P}>\mathrm{Z}=0.03)$. However, the coefficient for independent variable Getting Credit was not statistically significant, and therefore was not further considered.

As can be seen in Table 2, the increase of the average DTF indicator for Paying Taxes variable by 1 point reduces the total early entrepreneurship rate by 0.152 . In other words, if certain economy increases its average DTF ranking of Paying Taxes indicator for 10 points, the expected decrease of Total

Table 2. Random-effects GLS regression

\begin{tabular}{|c|c|c|c|c|c|c|}
\hline Number of obs $=100$ & \multicolumn{4}{|c|}{ Number of groups $=50$} & \multicolumn{2}{|c|}{ Obs per group $=2$} \\
\hline R-sq: within $=0.0133$ & & betwe & 2765 & & \multicolumn{2}{|c|}{ overall $=0.2592$} \\
\hline TEA & Coef. & Std. Err. & $\mathrm{z}$ & $\mathrm{P}>\mathrm{Z}$ & \multicolumn{2}{|c|}{ [95\% Conf. Interval] } \\
\hline Getting Credit & -0.007 & 0.033 & -0.22 & 0.827 & -0.071 & 0.057 \\
\hline Paying Taxes & -0.152 & 0.067 & -2.27 & 0.023 & -0.282 & -0.021 \\
\hline Resolving Insolvency & -0.065 & 0.030 & -2.15 & 0.032 & -0.125 & -0.006 \\
\hline _cons & 28.696 & 4.785 & 6.00 & 0.000 & 19.318 & 38.074 \\
\hline Wald $\operatorname{chi} 2(3)=16.62$ & \multicolumn{4}{|c|}{ Prob $>$ chi $2=0.0008$} & \multicolumn{2}{|c|}{$\operatorname{corr}\left(\mathrm{u} \_\mathrm{i}, \mathrm{X}\right)=0$ (assumed $)$} \\
\hline sigma_u = 6.1970293 & \multicolumn{4}{|c|}{ sigma_e $=2.5618323$} & \multicolumn{2}{|c|}{ rho $=0.85404612$} \\
\hline
\end{tabular}


early-entrepreneurship rate would be 1.52 percent higher. Similar can be said for Resolving Insolvency variable, except that this impact is more than twice lower. The increase of the average DTF ranking for Resolving Insolvency indicator for 10 points decreases TEA rate by 0.6 percent. The overall finding is that both coefficients are negative, which implies that the increase of observed indicators of financial regulation decreases early-entrepreneurship rate.

This paper has confirmed that some aspects of financial regulation system can have significant impact on development of early-stage entrepreneurial activity. Although this relation was generally described as positive in literature (better financial regulations provide better environment for entrepreneurs), this study has shown the opposite. Therefore, general perception regarding this matter should be considered with caution. The main reason for different conclusions can be the use of heterogeneous and time limited country sample, comprising the economies at different stage of economic development - from factor-driven to those innovation-driven.

Less developed factor-driven economies, which usually have less developed financial regulation, are characterized by high level of necessity-driven entrepreneurial activity. On the other hand, innovation-driven economies usually have high level financial regulations, accompanied by high percentage of opportunity-driven early stage entrepreneurship. Therefore, the examination of different types of early-stage entrepreneurship with the use of larger datasets could be the subject of some further analysis and could provide better insights into the relationship between financial regulations and entrepreneurship.

\section{REFERENCES}

Alesina, A., Ardagna, S., Nicoletti, G. \& Schiantarelli. F. (2005). Regulation and Investment. Journal of the European Economic Association, 3(4), 791-825.

DB. (2016). Doing Business, World Bank Group, available at http://www.doingbusiness.org/

De Araujo, A. P., Ferreira, R. D. V. X. \& Funchal, B. (2011). The Brazilian Bankruptcy Law Experiment. Working paper. Available at http://ssrn.com/ abstract $=1853984$.

Dewaelheyns, N., \& Van Hulle, C. (2008). Legal Reform and Aggregate Small and Micro Business Bankruptcy Rates: Evidence from the 1997 Belgian Bankruptcy Code. Small Business Economics, 31(4), 409-24.
Djankov, S., Ganser, T., McLiesh, C., Ramalho, R. \& Shleifer, A. (2010). The Effect of Corporate Taxes on Investment and Entrepreneurship. American Economic Journal: Macroeconomics, 2(3), 31-64.

Djankov, S., Hart, O. McLiesh, C. \& Shleifer, A. (2008). Debt Enforcement around the World. Journal of Political Economy, 116(6), 1105-49.

Djankov, S., McLiesh, C. \& Shleifer, A. (2007). Private Credit in 129 Countries. Journal of Financial Economics, 84(2), 299329.

Eifert, B. (2009). Do Regulatory Reforms Stimulate Investment and Growth? Evidence from the Doing Business Data, 2003-07. Working Paper 159, Center for Global Development, Washington, DC.

Fisman, R. \& Sarria-Allende, V. (2010). Regulation of Entry and the Distortion of Industrial Organization. Journal of Applied Economics, 13(1), 91-120.

Funchal, B. (2008). The Effects of the 2005 Bankruptcy Reform in Brazil. Economics Letters, 101, 84-86.

GEM. 2016. Global Entrepreneurship Monitor. Available at http://www.gemconsortium.org/

Giné, X., \& Love, I. (2010). Do Reorganization Costs Matter for Efficiency? Evidence from a Bankruptcy Reform in Colombia. Journal of Law and Economics, 53(4), 833-64.

Haselmann, R., Pistor, K. \& Vig, V. (2010). How Law Affects Lending. Review of Financial Studies, 23(2), 549-80.

Houston, J., Lin, C., Lin, P. \& Ma, Y. (2010). Creditor Rights, Information Sharing, and Bank Risk Taking. Journal of Financial Economics, 96(3), 485-512.

Klapper, L., Lewin, A., \& Delgado, J. M. Q. (2011). The impact of the business environment on the business creation process. In Entrepreneurship and Economic Development (pp. 108123). Palgrave Macmillan UK.

Perotti, E., \& Volpin, P. (2005). The Political Economy of Entry: Lobbying and Financial Development. Paper presented at the American Finance Association 2005 Philadelphia Meetings.

Rizzo, P. American Airlines Files for Bankruptcy Protection. NBC News (November 29, 2011).

Stampini, M., Leung, R., Diarra, S. M. \& Pla, L. (2011). How Large Is the Private Sector in Africa? Evidence from National Accounts and Labor Markets. IZA Discussion Paper 6267, Institute for the Study of Labor, Bonn.

Visaria, S. (2009). Legal Reform and Loan Repayment: The Microeconomic Impact of Debt Recovery Tribunals in India. American Economic Journal: Applied Economics, 1(3), 5981.

World Bank. (2011). Principles for Effective Creditor Rights and Insolvency Systems. Revised draft, January 20. http://www. worldbank.org/ifa/rosc_icr.html. 
Appendix 1. Complete dataset used

\begin{tabular}{|c|c|c|c|c|c|}
\hline Economy & Year & Getting Credit & Paying Taxes & Resolving Insolvency & TEA \\
\hline Argentina & 2015 & 50 & 44.99 & 45.1 & 17.74 \\
\hline Australia & 2015 & 90 & 82.44 & 81.6 & 12.79 \\
\hline Barbados & 2015 & 35 & 72.99 & 69.4 & 21.05 \\
\hline Belgium & 2015 & 45 & 73.84 & 83.87 & 6.24 \\
\hline Botswana & 2015 & 55 & 77.47 & 54.04 & 33.23 \\
\hline Brazil & 2015 & 45 & 40.85 & 54.52 & 20.98 \\
\hline Burkina Faso & 2015 & 30 & 58.08 & 38.08 & 29.75 \\
\hline Cameroon & 2015 & 35 & 36.34 & 36.42 & 25.37 \\
\hline Canada & 2015 & 85 & 93 & 81.36 & 14.72 \\
\hline Chile & 2015 & 50 & 84.5 & 47.38 & 25.93 \\
\hline China & 2015 & 50 & 64.04 & 55.31 & 12.84 \\
\hline Colombia & 2015 & 95 & 58.36 & 72 & 22.67 \\
\hline Croatia & 2015 & 55 & 82.92 & 53.92 & 7.69 \\
\hline Ecuador & 2015 & 45 & 62.84 & 28.36 & 33.56 \\
\hline Estonia & 2015 & 70 & 84.33 & 64.92 & 13.14 \\
\hline Finland & 2015 & 65 & 88.36 & 93.85 & 6.59 \\
\hline Germany & 2015 & 70 & 77.02 & 91.78 & 4.70 \\
\hline Greece & 2015 & 50 & 77.89 & 55.98 & 6.75 \\
\hline Guatemala & 2015 & 80 & 80.04 & 27.37 & 17.71 \\
\hline Hungary & 2015 & 75 & 73.27 & 49.78 & 7.92 \\
\hline India & 2015 & 65 & 56.14 & 32.6 & 10.83 \\
\hline Indonesia & 2015 & 50 & 53.66 & 46.75 & 17.67 \\
\hline Iran, Islamic Rep. & 2015 & 45 & 66.78 & 32.38 & 12.93 \\
\hline Ireland & 2015 & 70 & 95.07 & 78.46 & 9.33 \\
\hline Italy & 2015 & 45 & 63.35 & 75.98 & 4.87 \\
\hline Kazakhstan & 2015 & 50 & 89.85 & 51.45 & 11.00 \\
\hline Luxembourg & 2015 & 15 & 88.58 & 45.58 & 10.18 \\
\hline Malaysia & 2015 & 70 & 83.87 & 62.48 & 2.93 \\
\hline Mexico & 2015 & 80 & 71.17 & 72.59 & 21.01 \\
\hline Netherlands & 2015 & 50 & 86.76 & 83.77 & 7.21 \\
\hline Norway & 2015 & 55 & 90.93 & 85.62 & 5.66 \\
\hline Panama & 2015 & 75 & 48.6 & 33.66 & 12.80 \\
\hline Peru & 2015 & 80 & 79.48 & 46.57 & 22.22 \\
\hline Philippines & 2015 & 40 & 66.46 & 56.74 & 17.16 \\
\hline Poland & 2015 & 75 & 72.16 & 69.73 & 9.21 \\
\hline Portugal & 2015 & 45 & 77.84 & 84.19 & 9.49 \\
\hline Puerto Rico (U.S.) & 2015 & 85 & 63.83 & 84.88 & 8.48 \\
\hline Romania & 2015 & 85 & 80.09 & 58.7 & 10.83 \\
\hline Slovak Republic & 2015 & 65 & 69.62 & 69.93 & 9.64 \\
\hline Slovenia & 2015 & 35 & 83.74 & 62.91 & 5.91 \\
\hline South Africa & 2015 & 60 & 88.71 & 64.51 & 9.19 \\
\hline Spain & 2015 & 60 & 74.74 & 75.89 & 5.70 \\
\hline Sweden & 2015 & 55 & 83.46 & 78.43 & 7.16 \\
\hline Switzerland & 2015 & 60 & 89.13 & 62.6 & 7.31 \\
\hline Taiwan, China & 2015 & 60 & 82.9 & 78.41 & 7.30 \\
\hline Thailand & 2015 & 45 & 78.08 & 58.73 & 13.74 \\
\hline United Kingdom & 2015 & 75 & 90.62 & 82.04 & 6.93 \\
\hline United States & 2015 & 95 & 80.84 & 90.12 & 11.88 \\
\hline Uruguay & 2015 & 60 & 63.44 & 53.47 & 14.28 \\
\hline Vietnam & 2015 & 65 & 43.61 & 35.02 & 13.65 \\
\hline Argentina & 2014 & 62.5 & 44.99 & 33.17 & 14.41 \\
\hline Australia & 2014 & 93.75 & 82.47 & 87.54 & 13.14 \\
\hline Barbados & 2014 & 56.25 & 73 & 70.05 & 12.71 \\
\hline Belgium & 2014 & 56.25 & 74.06 & 95.77 & 5.40 \\
\hline Botswana & 2014 & 62.5 & 77.47 & 66.64 & 32.79 \\
\hline Brazil & 2014 & 42.69 & 40.85 & 21 & 17.23 \\
\hline Burkina Faso & 2014 & 43.75 & 58.08 & 19.84 & 21.71 \\
\hline Cameroon & 2014 & 43.75 & 36.34 & 16.58 & 37.37 \\
\hline Canada & 2014 & 81.25 & 93 & 93.96 & 13.04 \\
\hline
\end{tabular}




\begin{tabular}{|c|c|c|c|c|c|}
\hline Economy & Year & Getting Credit & Paying Taxes & Resolving Insolvency & TEA \\
\hline Chile & 2014 & 68.75 & 84.57 & 31.52 & 26.83 \\
\hline China & 2014 & 62.5 & 60.97 & 38.75 & 15.53 \\
\hline Colombia & 2014 & 62.5 & 61.6 & 73.47 & 18.55 \\
\hline Croatia & 2014 & 75 & 83.54 & 32.63 & 7.97 \\
\hline Ecuador & 2014 & 50 & 62.5 & 19.24 & 32.61 \\
\hline Estonia & 2014 & 75 & 84.16 & 41.87 & 9.43 \\
\hline Finland & 2014 & 75 & 88.45 & 97.11 & 5.63 \\
\hline Germany & 2014 & 81.25 & 76.84 & 89.54 & 5.27 \\
\hline Greece & 2014 & 56.25 & 81.29 & 36.56 & 7.85 \\
\hline Guatemala & 2014 & 87.5 & 76.48 & 29.83 & 20.39 \\
\hline Hungary & 2014 & 68.75 & 72.04 & 41.22 & 9.33 \\
\hline India & 2014 & 68 & 56.04 & 27.36 & 6.60 \\
\hline Indonesia & 2014 & 53.5 & 53.38 & 34.04 & 14.20 \\
\hline Iran, Islamic Rep. & 2014 & 62.5 & 66.78 & 20.35 & 16.02 \\
\hline Ireland & 2014 & 87.5 & 95.07 & 94.33 & 6.53 \\
\hline Italy & 2014 & 50 & 63.1 & 67.49 & 4.42 \\
\hline Kazakhstan & 2014 & 50 & 89.86 & 46.46 & 13.72 \\
\hline Luxembourg & 2014 & 25 & 88.58 & 46.82 & 7.14 \\
\hline Malaysia & 2014 & 100 & 83.99 & 52.69 & 5.91 \\
\hline Mexico & 2014 & 70.75 & 71.24 & 72.72 & 18.99 \\
\hline Netherlands & 2014 & 62.5 & 86.51 & 96.35 & 9.46 \\
\hline Norway & 2014 & 62.5 & 90.8 & 98.3 & 5.65 \\
\hline Panama & 2014 & 68.75 & 48.7 & 29.6 & 17.06 \\
\hline Peru & 2014 & 81.25 & 79.43 & 29.77 & 28.81 \\
\hline Philippines & 2014 & 56.25 & 66.46 & 22.91 & 18.38 \\
\hline Poland & 2014 & 93.75 & 72.19 & 58.99 & 9.21 \\
\hline Portugal & 2014 & 50 & 77.89 & 77.07 & 9.97 \\
\hline Puerto Rico (U.S.) & 2014 & 87.5 & 72.74 & 76.02 & 10.04 \\
\hline Romania & 2014 & 87.5 & 64.08 & 32.24 & 11.35 \\
\hline Slovak Republic & 2014 & 75 & 70.66 & 58.24 & 10.90 \\
\hline Slovenia & 2014 & 50 & 83.53 & 53.92 & 6.33 \\
\hline South Africa & 2014 & 81.25 & 88.8 & 38.23 & 6.97 \\
\hline Spain & 2014 & 68.75 & 75.33 & 77.84 & 5.47 \\
\hline Sweden & 2014 & 75 & 81.95 & 81.28 & 6.71 \\
\hline Switzerland & 2014 & 81.25 & 89.31 & 50.2 & 7.12 \\
\hline Taiwan, China & 2014 & 62.5 & 82.34 & 88.09 & 8.49 \\
\hline Thailand & 2014 & 62.5 & 76.93 & 45.43 & 23.30 \\
\hline United Kingdom & 2014 & 100 & 90.08 & 95.33 & 10.66 \\
\hline United States & 2014 & 86.25 & 80.85 & 86.49 & 13.81 \\
\hline Uruguay & 2014 & 62.5 & 62.44 & 48.5 & 16.08 \\
\hline Vietnam & 2014 & 68.75 & 43.61 & 17.43 & 15.30 \\
\hline
\end{tabular}

\section{Appendix 2. Statistical output}

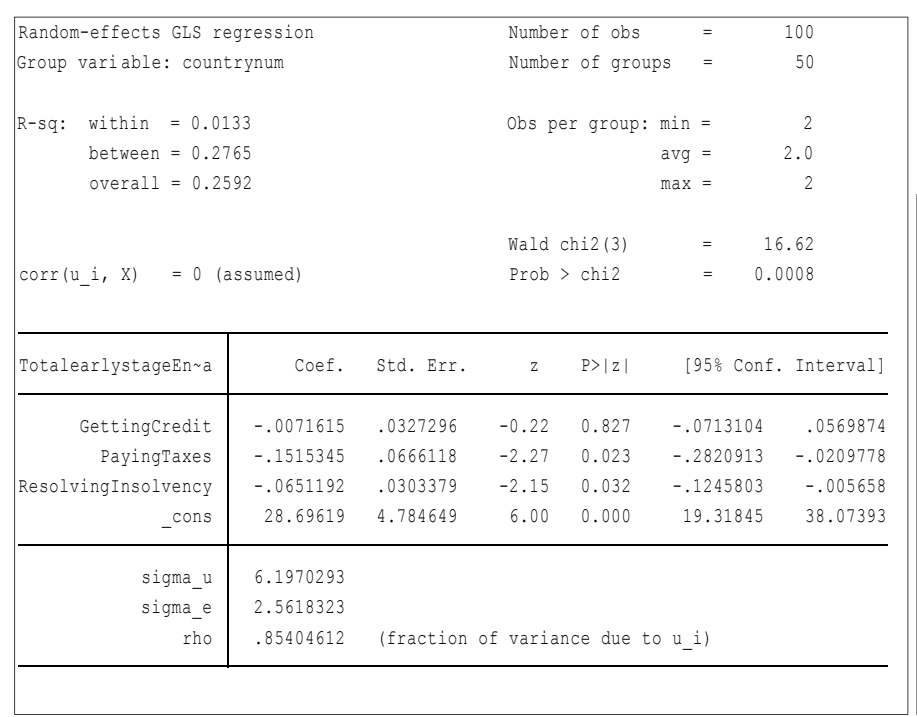

\begin{tabular}{|c|c|c|c|c|c|}
\hline & \multicolumn{2}{|c|}{- Coefficients -} & \multirow{3}{*}{$\begin{array}{c}(b-B) \\
\text { Difference }\end{array}$} & \multirow{3}{*}{$\begin{array}{l}\operatorname{sqrt}\left(\operatorname{diag}\left(V_{-} b-V_{-} B\right)\right) \\
\text { S.E. }\end{array}$} \\
\hline & & (b) & (B) & & \\
\hline & & fixed & random & & \\
\hline \multirow{3}{*}{\multicolumn{2}{|c|}{$\begin{array}{r}\text { GettingCre t } \\
\text { PayingTaxes } \\
\text { ResolvingI y }\end{array}$}} & .0219097 & -.0071615 & .0290712 & .0250768 \\
\hline & & -.0644183 & -.1515345 & .0871162 & . 1741786 \\
\hline & & -.01834 & -.0651192 & .0467791 & .0249493 \\
\hline \multirow{5}{*}{\multicolumn{2}{|c|}{ Test: Ho: }} & \multicolumn{4}{|c|}{$\begin{array}{l}\mathrm{b}=\text { consistent under } \mathrm{Ho} \text { and } \mathrm{Ha} \text {; obtained from xtreg } \\
\text { inconsistent under Ha, efficient under Ho; obtained from xtreg }\end{array}$} \\
\hline & & \multicolumn{4}{|c|}{ difference in coefficients not systematic } \\
\hline & & \multicolumn{3}{|c|}{$\operatorname{chi} 2(3)=(b-B)^{\prime}\left[\left(V_{-} b-V_{-} B\right)^{\wedge}(-1)\right](b-B)$} & \\
\hline & & $=$ & 3.89 & & \\
\hline & & Prob $>$ chi2 $=$ & 0.2737 & & \\
\hline
\end{tabular}




\section{UTICAJ FINANSIJSKIH REGULATIVA NA STOPU PREDUZETNIČKE AKTIVNOSTI U RANOM STADIJUMU}

\section{Apstrakt:}

Napori koje Vlada preduzima da stvori bolje poslovno okruženje u smislu visoko-kvalitetnih regulativa i poslovnih zakona trebalo bi da podstaknu razvoj preduzetničke aktivnosti na različite načine. Određeni izvori u literaturi potvrđuju pomenutu izajvu. Cilj rada jeste da ispita kako su različite vrste finansijskih regulativa, poput procedura za dobijanje kredita, plaćanje poreza i rešavanje stečajnog postupka, u vezi sa osnivanjem preduzeća. Uzorak je obuhvatio Izveštaj Svetske banke o poslovanju i podatke globalne studije o preduzetništvu (GEM) za 50 zemalja u periodu od dve godine. Istraživanje je pokazalo da finansijske regulative mogu imati značajan uticaj na stopu preduzetničke aktivnosti u ranom stadijumu, ali taj odnos ne mora nužno biti definisan kao pozitivan.

\section{Ključne reči:}

preduzetništvo,

finansijska politika, poslovanje,

regulative. 